\section{Pacific Northwest}

National Laboratory

Operated by Battelle for the

U.S. Department of Energy

\title{
Melt Rate Improvement for High-Level Waste Glass
}

\author{
Josef Matyáš \\ Pavel Hrma \\ Dong-Sang Kim
}

August 2002

Prepared for the U.S. Department of Energy

under Contract DE-AC06-76RL01830 


\title{
Disclaimer
}

This report was prepared as an account of work sponsored by an agency of the United States Government. Neither the United States Government nor any agency thereof, nor Battelle Memorial Institute, nor any of their employees, makes any warranty, express or implied, or assumes any legal liability or responsibility for the accuracy, completeness, or usefulness of any information, apparatus, product, or process disclosed, or represents that its use would not infringe privately owned rights. Reference herein to any specific commercial product, process, or service by trade name, trademark, manufacturer, or otherwise does not necessarily constitute or imply its endorsement, recommendation, or favoring by the United States Government or any agency thereof, or Battelle Memorial Institute. The views and opinions of authors expressed herein do not necessarily state or reflect those of the United States Government or any agency thereof.

\author{
PACIFIC NORTHWEST NATIONAL LABORATORY \\ operated by \\ BATTELLE \\ for the \\ UNITED STATES DEPARTMENT OF ENERGY \\ under Contract DE-ACO6-76RLO183O
}

Printed in the United States of America
Available to DOE and DOE contractors from the Office of Scientific and Technical Information,
P.O. Box 62, Oak Ridge, TN 37831-0062;
ph: (865) 576-8401
fax: $(865) 576-5728$
email: reports@adonis.osti.gov

\begin{abstract}
Available to the public from the National Technical Information Service, U.S. Department of Commerce, 5285 Port Royal Rd., Springfield, VA 22161 ph: (800) 553-6847 fax: $(703) 605-6900$

email: orders@ntis.fedworld.gov

online ordering: http://www.ntis.gov/ordering.htm
\end{abstract}

This document was printed on recycled paper. 
PNNL-14003

\section{Melt Rate Improvement for High-Level Waste Glass}

Josef Matyáš

Pavel Hrma

Dong-sang Kim

August 2002

Prepared for the U.S. Department of Energy under Contract DE-AC06-76RL01830

Pacific Northwest National Laboratory

Richland, Washington 99352 


\section{Summary}

An efficient waste-glass melter should have a sustained, high-volume glass throughput. A more efficient operation at higher capacities would result in a smaller vitrification facility, a shorter lifecycle, and glass with a higher concentration of waste, all of which would reduce costs significantly. These benefits would enhance the vitrification of waste at several current and future U.S. Department of Energy sites, including Savannah River, Hanford, and Idaho.

This research is based on a workable hypothesis to control the rate of melting in a high-level waste melter. Its objective is to develop methods for increasing the melting rate, to quantitatively describe the phenomena underlying melt-rate problems, and to propose the ways to solve or mitigate them.

This report summarizes results of research accomplished during the first year of the 3-year project. The data presented in this report have been gathered to support work on the mathematical modeling of waste-glass melters. At this stage, only a qualitative description and interpretation of the observed phenomena has been attempted.

Two Savannah River feeds were used for the study. These feeds were subjected to thermal gravimetric analysis, differential thermal analysis, differential scanning calorimetry, evolved gas analysis with volume-expansion monitoring, modified reboil test, quantitative X-ray diffraction, scanning electron microscopy with energy dispersive spectroscopy, wet chemical analysis, and Mössbauer spectroscopy. Glass viscosity was also measured. Finally, it was recommended to use melt-rate furnace test data to measure thermal diffusivity of the feed.

Though both feed were reduced to prevent oxygen evolution from the melt, oxygen evolved form one of the melts and $\mathrm{CO}_{\mathrm{x}}$ evolved from both. Hence, foam is likely to form under the cold cap even when the feed is reduced. An important difference between the feeds was in the melt viscosity at the temperature at which the melt interfaces the cold cap. It was suggested that low viscosity destabilizes foam under the cold cap, thus enhancing the rate of melting. 


\section{Acronyms}

DOE U.S. Department of Energy

DSC differential scanning calorimetry

DTA differential thermal analysis

DWPF Defense Waste Processing Facility

EGA evolved gas analysis

GC-MS gas chromatography-mass spectrometry

HLW high-level waste

LAW low-activity waste

PNNL Pacific Northwest National Laboratory

RSM research-scale melter

RT room temperature

SEM EDS scanning electron microscopy with energy-dispersive spectroscopy

SRTC Savannah River Technology Center

TGA thermo-gravimetric analysis

UV-VIS-NIR ultraviolet visible near infrared

WTP Waste Treatment Plant

XRD $\quad \mathrm{x}$-ray diffraction 


\section{Acknowledgments}

We would like to acknowledge the input of David Peeler from Westinghouse Savannah River Company. David and his team (Doughlas Witt, Dennis Bickford, Troy Lorier, et al.) were involved in discussions of the planned scope of work and provided a number of useful comments to this report. We would also like to thank Bill Holtzscheiter from the Tanks Focus Area (Immobilization Technology Integration Manager) for his guidance, help, and support. This work was funded by the U.S. Department of Energy Office of Science and Technology under the Tanks Focus Area and was performed at the Pacific Northwest National Laboratory, which is operated for the U.S. Department of Energy by Battelle under Contract DE-AC06-76RL01830. 


\section{Contents}

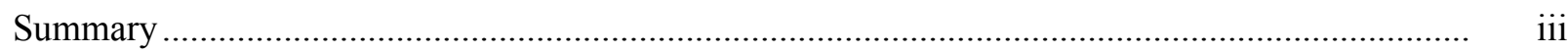

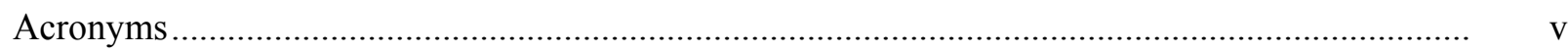

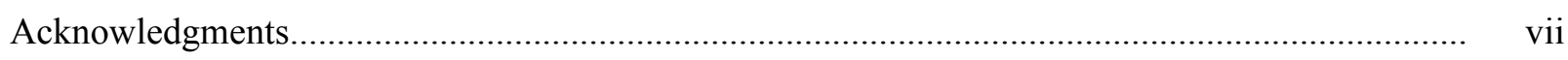

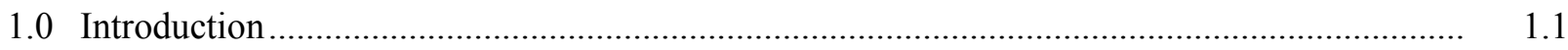

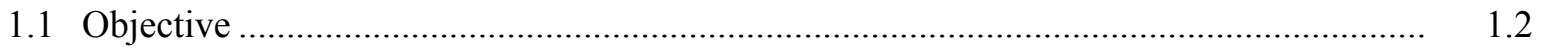

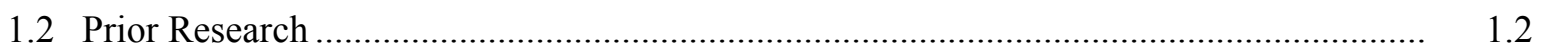

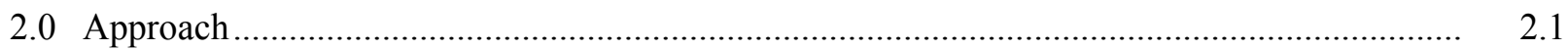

2.1 Feed Selection and Heat-Treatment Schedule.............................................................

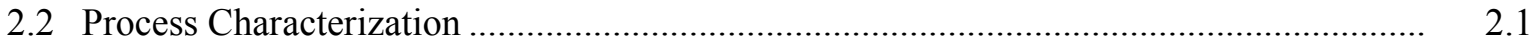

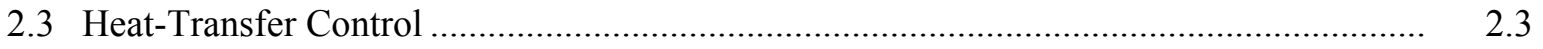

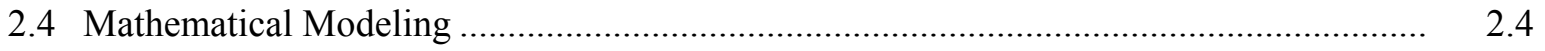

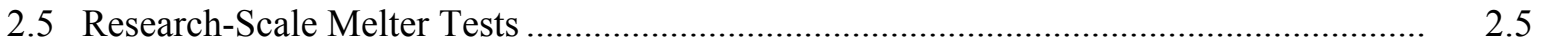

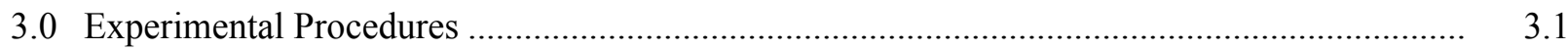

3.1 Thermal Gravimetric Analysis, Differential Thermal Analysis, and Differential

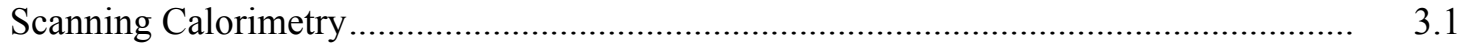

3.2 Evolved Gas Analysis with Volume-Expansion Monitoring ...................................... 3.1

3.3 Modified Reboil Test and Bubble Analysis ........................................................... 3.1

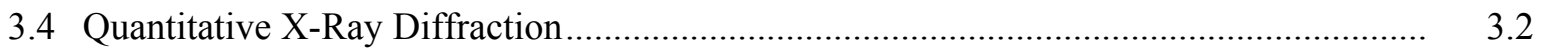

3.5 Scanning Electron Microscopy and Energy Dispersive Spectroscopy............................ 3.2

3.6 Wet Chemical Analysis and Mössbauer Spectroscopy …............................................ 3.2

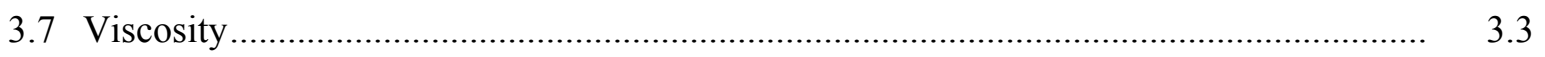

3.8 Thermal Diffusivity (using melt-rate furnace test data) ............................................. 3.3

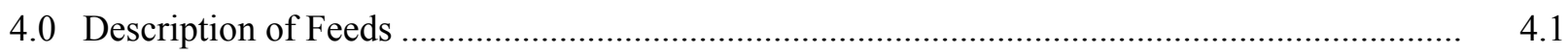

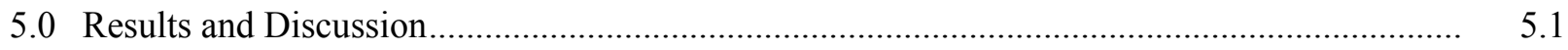

5.1 Thermal Gravimetric Analysis, Differential Thermal Analysis, and Differential Scanning Calorimetry 
5.2 Analysis of Evolved Gas with Volume-Expansion Monitoring ...................................... 5.6

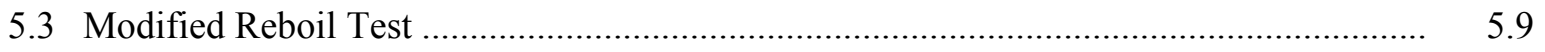

5.4 Quantitative X-Ray Diffraction.......................................................................... 5.13

5.5 Scanning Electron Microscopy and Energy Dispersive Spectroscopy............................ $\quad 5.16$

5.6 Mössbauer Spectroscopy and Wet Chemical Analysis .............................................. 5.17

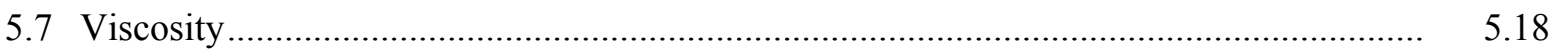

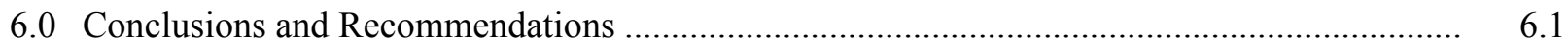

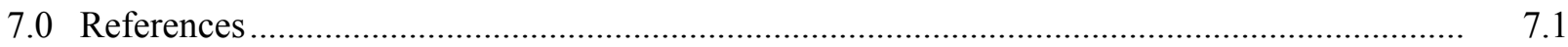

\section{Figures}

1.1. Schematic Cross-Section of a Glass Melter.

2.1. Photograph of Research-Scale Melter............................................................................. 2.6

5.1. TGA Mass Loss of DWPF Macrobatch 3 Feeds Versus Temperature .....................................

5.2. TGA Mass Loss Rate of DWPF Macrobatch 3 Feeds Versus Temperature ............................ 5.2

5.3. DTA Traces (Temperature Difference Versus Temperature) for DWPF Macrobatch 3 Feeds 5.3

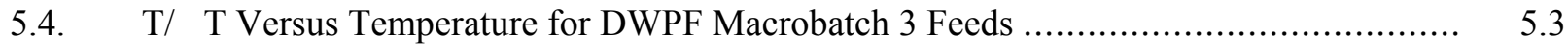

5.5. DSC Conversion Heat Rate versus Temperature for DWPF Macrobatch 3 Feeds ................... $\quad 5.4$

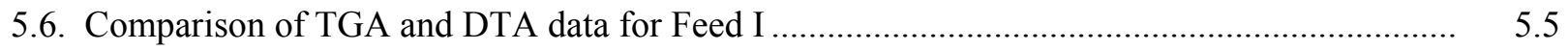

5.7. Comparison of TGA and DTA data for Feed II .......................................................... 5.5

5.8. The Rate of Gas Evolution and Relative Volume Expansion of 10-g Feed I ......................... 5.7

5.9. The Rate of Gas Evolution and Relative Volume Expansion of 10-g Feed II ....................... 5.7

5.10. The Rate of Gas Evolution from 48.6-mg Feed I..................................................................

5.11. The Rate of Gas Evolution of 48.6-mg Feed II........................................................... 5.9

5.12. Evolved Gas Composition of 10-g Feed I (GS-MS data) …............................................ 5.10

5.13. Evolved Gas Composition of 10-g Feed II (GS-MS data) ................................................ 5.10

5.14. Evolved Gas Composition of 10-g Feed I (MS data) ..................................................... 5.11 
5.15. Evolved Gas Composition of 10-g Feed II (MS data)

5.16. Fractions of Feed Minerals Versus Temperature in Feed I.............................................. 5.14

5.17. Fractions of Feed Minerals Versus Temperature in Feed II ............................................

5.18. Mass Fractions of Intermediate Crystalline Phases in Feed I .......................................... 5.15

5.19. Mass Fractions of Intermediate Crystalline Phases in Feed II ........................................... 5.15

5.20. RT Mössbauer Spectrum of Glass I (MB3 with Frit 200) Quenched from $900^{\circ} \mathrm{C} \ldots \ldots \ldots \ldots \ldots \ldots . . . . . . .17$

5.21. Wet Colorimetry and Mössbauer Spectroscopy Fe(II)/Fe(III) Values for Glasses I, II .......... $\quad 5.18$

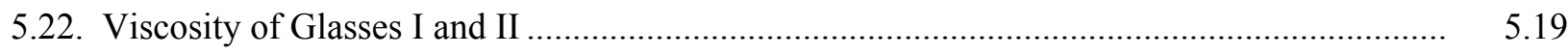

5.23. Viscosity of Glasses I and II, Arrhenius Plot................................................................

\section{Tables}

4.1. Composition of Baseline Macrobatch 3(a) ......................................................................

4.2. Nominal Composition of Frits in Mass $\%$................................................................................

4.3. DWPF Glass Compositions in Mass Fractions ............................................................

5.1. Total Mass Losses (in mass\%) of DWPF Macrobatch 3 Feeds ........................................... 5.2

5.2. Mass Losses of DWPF Macrobatch 3 Feeds....................................................................... 5.6

5.3. Maximum Volume Expansion (in vol\%) and Total Volume of Batch Gases (in mL/g glass) Evolved from 10-g DWPF Macrobatch 3 Feeds ........................................... 5.8

5.4. Volumes of Reboil Gases ( in $\mathrm{mL} / \mathrm{kg}$ glass) Evolved during the Heat Treatment of DWPF Macrobatch 3 Feeds.

5.5. Wet Chemistry Analysis of Fe(II) and Fe(III) in Glasses I and II ..................................... 5.18 